\title{
Die Kerkhervorming in Hongarye ${ }^{1}$
}

\author{
K D Papp (Nigel) \\ Departement Kerkgeskiedenis en Kerkreg \\ Universiteit van Pretoria
}

\begin{abstract}
The Reformation in Hungary

This article focuses on a description of the Reformation in Hungary. Research into the historical backgrounds of the South-African clerical family Papp (of which the progenitor, the Reverend Kálmán Papp, is the only Hungarian immigrant to date to have become a minister in the reformed churches of South Africa), provided the stimulus for the exploration of this topic. The article briefly describes the political and ecclesiastical circumstances in Hungary prior to the Reformation, the course thereof, with specific reference to the most prominent Hungarian reformers, the outcome of the Reformation, as well as the birth of the Reformed Church of Hungary. The influence of Heinrich Bullinger, whose Confessio Helvetica Posterior was accepted as an official article of faith of this church in 1567, is dealt with in more detail. The article concludes with a few cursory remarks on the effects of the ecclesiastical and political developments in Hungary on the church in the sixteenth century and also provides some statistical data with regard to the present situation.
\end{abstract}

\section{INLEIDING}

Die geskiedenis van die Kerkhervorming vorm 'n belangrike deel van die kurrikulum van die vak Kerkgeskiedenis in die meeste opleidings van die Reformatoriese familie van kerke. In Suid-Afrika word daar uit die aard van die saak besondere klem gelê op die geskiedenis van die Kerkhervorming in die Suid-Afrikaanse stamlande. Die verloop van die Hervorming in ander lande geniet minder aandag en is gevolglik betreklik onbekend.

\footnotetext{
${ }^{1}$ Hierdie artikel is gebaseer op 'n gedeelte uit die MA-verhandeling van K D Papp, getitel "Die historiese agtergronde van die Hongaars-Afrikaanse predikantefamilie Papp". Die verhandeling is voorberei onder die leiding van prof dr S J Botha, Fakulteit Teologie, Universiteit van Pretoria (2002). Ds K D Papp, predikant van die Nederduitsch Hervormde Gemeente Nigel, is 'n PhDstudent in die Departement Kerkgeskiedenis, Universiteit van Pretoria.
} 
Tydens navorsing met die oog op 'n MA-verhandeling getiteld Die historiese agtergronde van die Hongaars-Afrikaanse predikantefamilie Papp, is die geskiedenis van die Kerkhervorming in Hongarye onder andere onder die loep geneem. Die stamvader van hierdie familie is ds Kálmán Papp, predikant van die Nederduitsch Hervormde Kerk van Afrika sedert 1951 en tot op hede die enigste Hongaarsgebore persoon wat predikant van 'n Reformatoriese kerk in Suid-Afrika geword het. Ds Papp is afkomstig uit 'n tradisieryke Hongaarse predikantefamilie waarin daar minstens sewentien predikante voorkom. Hierdie artikel is 'n poging om kortliks iets van die geskiedenis van die Kerkhervorming in Hongarye te beskryf.

\section{POLITIEKE EN KERKLIKE AGTERGROND}

Aan die einde van die Middeleeue het Hongarye, net soos die meeste ander lande in Europa, begin wegbeweeg van 'n feodale stelsel in die rigting van 'n kapitalistiese sisteem. Die opkoms van die Rennaissance het hierin 'n enorme rol gespeel. Die kerk was nie meer die enigste instansie wat mense se lewens- en wêreldbeskouings bepalend beïnvloed het nie; filosowe, skrywers, kunstenaars, natuurwetenskaplikes en andere het hulle eie reëls begin maak.

Na die dood van koning Mátyás Hunyadi van Hongarye in 1490, was sy babaseun János veronderstel om hom op te volg. Hy het egter nooit die troon bestyg nie aangesien hy deur die Hongaarse Ryksdag, bestaande uit verteenwoordigers van die grondmagnate en adelstand, as te jonk geag is. Hulle het Ulászló II, koning van Bohemië, wat nie baie dinamies was nie en gevolglik nie vir hulle 'n bedreiging ingehou het nie, toe as koning aangewys. János het as troosprys koning van Bosnië geword en beheer oor die suidelike provinsies van Hongarye ontvang. Hy het in 1504 tydens 'n veldslag teen die Turke gesneuwel.

Ulászló II se magte is aansienlik ingeperk deur sy voorganger se desentralisasie van veral administratiewe magte aan die grondbaronne en hoë kerklike ampsdraers. Dit het tot talle wanpraktyke aanleiding gegee. Tamás Bakócz, aartsbiskop van Esztergom, het homself byvoorbeeld só verryk met belastings wat vir die monargie bestem was, dat die prag en praal van sy paleis dié van die koning oorskadu het. Ulászló II, wat maar 'n besluitelose karakter was, het die koningshuis se uitgawes ter wille van oorlewing met belastings vanuit Bohemië befonds en gelate toegekyk hoedat die monargie by die dag verarm. Pogings van die adellikes en baronne om hom te onttroon het hom 
uiteindelik gedwing om by die Habsburgers hulp te gaan soek. In ruil hiervoor moes hy aansienlike minerale regte aan die Habsburgers toeken. Die grondbaronne en adellikes het in hulle strewe na rykdom intussen ook begin om die boere só met hoë belastings te verarm dat dit uiteindelik gelei het tot die grootste boere-opstand in die hele geskiedenis van Hongarye (kyk Pamlényi 1973:116).

In 1514 a Crusade army was recruited among the serfs; subsequently, as the landowners resented their serfs' prolonged absence from the fields, it was ordered to demobilize. The soldiers resisted this order, first by robbing the estates and then in open revolt under the leadership of a petty-nobleman, György Dózsa. The rising was defeated, and bloody retribution followed: 70,000 peasants were killed; Dózsa was burnt alive on a white-hot throne as "the king of the peasants", and his followers were compelled to pick the flesh from his bones and eat it.

(Ignotus 1972:31)

Ulászló II se versoek om hulp het in 1515 gelei tot 'n dubbele huweliksooreenkoms met die Habsburgers, waarvolgens Ferdinand, Aartshertog van Oostenryk, met Anna, die dogter van Ulászló, en Lajos, die seun van Ulászló, met Ferdinand se suster, Maria, in die huwelik sou tree. Hierdie ooreenkoms is aangegaan op die vooraand van die Turkse inval in Hongarye en het 'n groot mate van permanensie verleen aan Hongarye se bande met die Habsburgers. Lajos het kragtens die ooreenkoms van 1515 'n jaar later koning van Hongarye geword.

Karel van Habsburg, wat in 1519 tot Keiser van die Heilige Romeinse Ryk verkies is, kon vanweë verpligtinge in die weste en wanorde in die Duitse ryk egter nie 'n groot leër stuur om Hongarye by te staan toe die Turke met hulle aanslag teen Hongarye begin het nie. In 1521 moes Hongarye gevolglik die stad Nándorfehérvár, in die suide van die land, aan die Turke afstaan omdat hulle nie teen die oormag bestand was nie. 'n Hulpkreet tot die Duitse Ryksdag het ook op dowe ore geval en Hongarye se weerbaarheid is verder verswak deur 'n groot mynwerkersopstand aan die begin van 1526 (kyk Pamlényi 1973:118).

Die bogenoemde gebeure het netjies ingepas by die planne van Turkye se sultan Suleiman II naamlik om met sy groot offensief teen Hongarye te begin. Kort daarna het hy dan ook van die geleentheid gebruik gemaak deur Hongarye 
vanuit die suide binne te val. Die Hongaarse leërs het in Augustus 1526 te Mohács, 'n dorp aan die Donaurivier en toegangspoort tot die Transdonause provinsie en die Hongaarse Laagvlakte, ' $n$ verpletterende neerlaag teen die Turke gely en koning Lajos II het tydens hierdie slag sy lewe verloor. Hierdie neerlaag word vandag nog deur die Hongare as een van die grootste rampe in hulle geskiedenis beskou. Tydens hierdie oorlog het ses van die twaalf biskoppe van Hongarye ook hulle lewens op die slagveld verloor. Dit het die leierskorps van die Rooms-Katolieke Kerk gedurende die tyd van die Kerkhervorming aansienlik uitgedun (sien Bucsay 1985:19).

Suleiman het tot in Buda opgeruk maar sy troepe kort daarna uit Hongarye onttrek omdat hy verneem het dat 'n groot Hongaarse leër onder leiding van baron János Szápolyai, een van die rykste en magtigste baronne van die land, op pad was om hulle aan te val. Die dood van koning Lajos het ruimte geskep vir Szápolyai om beheer van Hongarye oor te neem, maar die Habsburgers was net so gretig om hulle heerskappy in Sentraal-Europa te vestig. Szápolyai is toe deur sy volgelinge, wat hoofsaaklik uit die adelstand bestaan het, tot koning gekroon, terwyl die Habsburgers Ferdinand I, die jonger broer van keiser Karel V, tot koning verklaar het. Koning Ferdinand het Szápolyai kort daarna aangeval en gedwing om na Pole, waar sy swaer koning was, uit te wyk. Daar het 'n Poolse aristokraat, Jeromost Laski, hom aanbeveel om homself vrywilliglik onder die beskerming van die sultan te laat plaas. Suleiman het hierdie aanbod aanvaar en Szápolyai het onder sy beskerming na Hongarye teruggekeer en sy heerskappy in Buda en Transsilvanië, in die ooste van die land, gevestig. Koning Ferdinand het egter die noordelike en westelike provinsies van Hongarye vir die Habsburgers behou, terwyl die Turke die suidelike provinsies onder hulle beheer gehad het.

Toe Szápolyai in 1540 oorlede is, het sy ondersteuners sy babaseun, János Zsigmond, tot koning verklaar. Suleiman het Buda egter ' $n$ jaar later beset en János het slegs in beheer van die oostelike deel van Hongarye, ongeveer $50 \%$ van die land, gebly. Hierdie verdeling van Hongarye in drie afsonderlike dele, het vir 150 jaar voortgeduur. Suleiman se besetting van Buda het duidelik laat blyk dat hy nie bereid sou wees om die land onder János te laat verenig nie. 'n Vertroueling van Szápolyai, biskop György Martinuzzi, wat hom oor koning János en sy ma, Izabella, ontferm het, het die oostelike koninkryk met die oog op die moontlike hereniging van Hongarye toe aan koning Ferdinand aangebied. 
Laasgenoemde het die aanbod aanvaar en Transsilvanië in 1551 onder Habsburgse beheer geplaas. Hy is egter in 1556 deur die Turke verdryf en Suleiman het Izabella en János weer aan bewind geplaas en die Szápolyaidinastie in ere herstel.

\section{DIE KERKHERVORMING IN HONGARYE}

\subsection{Aanloop tot en aanvang en verloop van die Kerkhervorming}

Die Kerkhervorming het vroeg en baie vinnig op Hongaarse bodem grondgevat, ten spyte van die bogenoemde ongunstige omstandighede naamlik Turkse (Moslemse) oorheersing in die sentrale en suidelike dele van die land, ' $n$ byna afsonderlike koninkryk in die oostelike deel (Transsilvanië) en oorheersing van die noordelike en westelike dele deur die Habsburgers, asook die feit dat beide die Christelike konings in die ooste én die noord-weste van Hongarye, nie baie groot simpatie getoon het met die bewegings wat die Kerkhervorming voorafgegaan het nie.

Daar was egter ook enkele gunstige faktore. Hongarye het in dié tyd, in teenstelling met die meeste ander volke, sterk bande met sy buurvolke, veral in die weste, gehandhaaf. Talle Hongaarse studente het byvoorbeeld in Krakau, Parys, Bologna, Praag en Wene studeer in die eeu voor die Kerkhervorming (sien Révész 1956:4). Hier het hulle in aanraking gekom met al die nuwe bewegings en ontwikkelings in die teologie en dit met hulle terugkeer na Hongarye saamgebring. Ook sakemanne en diplomate het met hierdie nuwe gedagtes na hulle vaderland teruggekeer. Kontak met die buurlande was natuurlik nie net 'n verskynsel van hierdie tyd nie. Bucsay maak daarvan melding dat die Hongaarse Christendom reeds vroeg in die dertiende eeu al intieme kontak met die groter Christelike wêreldgemeenskap gehad het en sy eenheid met hierdie gemeenskap gehandhaaf het:

König András II (1205-1235) führte 1217 einen Kreuzzug ins Heilige Land, der ihm allerdings außer dem leeren Titel eines "Königs von Jerusalem" nichts einbrachte. Der Ungarische König und römische Kaiser Sigismund hatte auf dem Konzil zu Konstanz gegen die abendländische Kirchenspaltung zu kämpfen: Gegen Hus erreichte er einen recht zweifelhaften Erfolg. Der ungarische Reichsverweser und Feldherr János [Johann] Hunyadi hielt die große Offensive der Türken 
an der Südgrenze Ungarns auf. Seinen grandiosen Sieg bei Belgrad (1456) bejubelte die ganze christliche Welt.

(Bucsay 1977:30)

Studente en dosente het ook gedurende die Middeleeue bygedra tot kontak met die Christelike lewe in die buiteland. Die name van Hongaarse studente kom byvoorbeeld in die universiteitsregisters van Bologna voor in 1221, 1461, 1471 en 1472. Honderd en sestien Hongaarse professore het tussen 1385 en 1495 aan die Fakulteit Filosofie en dertien tussen 1407 en 1477 aan die Fakulteit Teologie van die Universiteit van Wene gedoseer (kyk Bucsay 1977:31). Dit is dus duidelik dat die Hongaarse kerk reeds in die Middeleeue 'n aktiewe lid van die westerse Christendom was.

Die herlewing van die humanistiese bewegings aan die begin van die sestiende eeu het die saak van die Hervorming in Hongarye ook gedien in dié sin dat dit onder andere die gesag van die Roomse Kerk bevraagteken het. Die Renaissance het dus nie net 'n enorme invloed op die kultuur en regte van individue uitgeoefen nie, maar ook op die godsdiens en die kerk. Daar dien hier gemeld te word dat die vroeë Humanisme Hongarye reeds in die veertiende eeu uit Italië en Bohemië binnegekom het (sien Bakhuizen van den Brink \& Dankbaar 1967:128 en 129).

Benewens die bogenoemde gunstige faktore moet daar ook in gedagte gehou word dat Hongarye ook gedurende die Middeleeue 'n gesogte nedersettingsgebied was. Bucsay stel dit soos volg:

Ungarn war im ganzen Mittelalter auch ein bevorzugtes Siedlerland. Zahlreiche deutsche Städte in West- und Nordungarn sowie in Siebenbürgen, französische und italienische Handwerker, die in den Städten Ungarns ganze Straßenzüge bewohnten, Tschechen und Mährer in Oberungarn, die zuerst als hussitische Krieger ins Land gekommen waren, sich aber letztlich friedlich niederließen, sorgten für dauernde und umfassende Verbindung met dem Auslande. So ist es kein Wunder, daß mittelalterliche kirchliche Erneuerungsideen, vor allem die des Hussitentums, rasch in Ungarn eindrangen und hier lebhaften Widerhall fanden. Schließlich darf in der Reihe der die Reformation vorbereitenden Faktoren nicht unerwähnt bleiben, daß Ungarn damals wie heute direk an den Bereich der orientalischen Orthodoxie grenzte, orthodoxe Ruthenen und Romänen in großen 
Scharen in seiner Grenzen aufgenommen hatte, und daß ihm daher die Vorstellung eines romfreien Christentums nie fremd war!

(Bucsay 1977:37)

In Hongarye self het daar aan die einde van die vyftiende- en begin van die sestiende eeu intussen 'n aantal persone na vore getree wat begin het om die Skrif uit te lê en die evangelie te verkondig, in teenstelling met die algemene praktyk van daardie tyd. Die preke van ene Pelbárt van Temesvár, is tussen die jare 1498 en 1521 byvoorbeeld 52 keer herdruk (kyk Bucsay 1977:37). Hierdie preke, wat onder andere die gelykheid van alle mense voor die aangesig van God beklemtoon het, is gretig deur die arbeidersklas gelees, veral tydens die boere-opstand van 1514. Die onverdiende genade en troos van God, wat die tema van baie van hierdie preke is, het goed op die oor geval toe dieselfde opstand wreed onderdruk is.

Die leerstellings van Martin Luther (1483-1546) het baie gou in die stede en plattelandse gebiede van Hongarye bekend en gewild geword. Die RoomsKatolieke Kerk het onmiddellik hierin 'n bedreiging gesien en György Szathmáry (1457-1524), Primaat-aartsbiskop van Esztergom, het in 1521 opdrag gegee dat die pouslike bul waarin die leerstellings van Luther veroordeel is, vanaf elke kansel in die land afgelees moet word (kyk Révész 1956:6).

Omdat Duits in daardie stadium die lingua franca was, is Luther se leerstellings nie net vanaf die kansels verkondig nie, maar ook wyd en syd gelees, veral in die Duitssprekende handelsstede van Hongarye. Die Rooms Katolieke Kerk en pous is reeds in 1522 vanaf kansels in die stad Sopron veroordeel. Die gevolg hiervan was dat daar in 1524 en 1526 gesante daarheen gestuur is om hierdie uitgesproke predikers die mond te snoer. Die situasie het ook vir die staat 'n bedreiging ingehou, in so 'n mate dat die Hongaarse Ryksdag in 1523 Protestante met swaar strawwe, onder andere die brandstapeldood, gedreig het. "Omnes lutheranos et illorum fautores, ac factioni ipsi adhaerentes, tamquam publicos haereticos hostesque sacratissimae virginis Mariae poene capitis et ablatione minium bonorum suorum Majestas Regia, veluti catholicus princeps, punire dignetur" (Zsilinszky 1881:14). Twee jaar later het die Ryksdag die volgende besluit daaraan toegevoeg: "Lutherani mones de regno exstirpentur et ubicumque reperti fuerint, non solum per ecclesiasticos, verum etiam per 
seculares personas libere capiantur et comburantur" (Zsilinszky 1881:20). Verskeie prominente hervormingsgesindes het as gevolg hiervan na die buiteland uitgewyk terwyl ander in die tronk beland het (kyk Révész 1956:7). Die Turkse invalle het egter veroorsaak dat daar min van die toepassing van hierdie besluite tereggekom het.

In 1522 skryf die eerste studente vanuit Hongarye aan die Universiteit van Wittenberg in om persoonlik onder Luther en Melanchton (1497-1560) te studeer. Aanvanklik was dit slegs Duitssprekendes wat daar gaan studeer het, maar sedert 1529 het talle Hongaarssprekendes ook in Duitsland verder gaan studeer (kyk Szabó 1927:7). Die meeste van hierdie studente het na afloop van hulle studies na hulle vaderland teruggekeer en die Protestantse leer met groot ywer en vuur oral in die land verkondig.

Hierbenewens is die neerlaag van die Hongaarse magte te Mohács teen die Turke in 1526, deur die meerderheid van die bevolking geïnterpreteer as God se straf vir die korrupsie van die Rooms-Katolieke Kerk. "Thus the religious and ethical condition of the nation was fertile soil in which the seeds of the Gospel could be sown through the comforting message of the Reformers' preaching" (Hervormde Kerk van Hongarye 1997:7 = HKH 1997:7). Tydens die Turkse opmars na Buda het die hele bevolking in opstand gekom teen die Moslemindringers. Beide die adelstand én arbeidersklas het eweveel onder die aanslag van die Turke gely. Die gevolg was dat beide groepe die Christelike geloof met die nasionale belang van Hongarye geïdentifiseer het en in die boodskappe van die Hervormers dié vorm van die Christelike geloof gevind het wat hulle nodig gehad het om hulle van krag te voorsien om die indringers te weerstaan.

The reformed faith brought with it, moreover, both a communal reformation in morals and an inner strength to the soul of the individual, conscious, as he became, of personal salvation in Christ. That is to say, to the Hungarian, without dubiety to be "reformed" at the time of the Reformation meant to experience a real conversion of heart.

(Révész 1956:8)

Toe koningin Izabella in 1559 oorlede is, was haar jong seun János nog nie in staat om die regering van Transsilvanië by haar oor te neem nie. Die bestuur van die koninkryk is toe oorgeneem deur István Báthory, 'n magtige aristokraat van 
die Tiszastreek. In die belang van vrede en met die oog op die inperking van Turkse en Habsburgse ekspansionisme het hy konings János en Ferdinand I oorreed om hulleself te versoen met die verdeling van die land. In 1568 het hy na baie moeite daarin geslaag om sultan Selim II, die opvolger van Suleiman, en keiser Maximilian II, die opvolger van Ferdinand I, 'n ooreenkoms te laat sluit waarkragtens die verdeling amptelik aanvaar is. In 1570 is 'n tweede ooreenkoms aangegaan waarkragtens János van die troon van Transsilvanië afstand gedoen het en as prins oor die prinsdom van Transsilvanië, 'n vasalstaat van die Turke, aangebly het. Die noordwestelike deel van Hongarye het hierna as die Koninkryk van Hongarye deel van die Habsburgse ryk geword. Na die dood van prins János in 1571, het István Báthory prins van Transsilvanië geword (kyk Pamlényi 1973:129).

Báthory het Transsilvanië met groot onderskeiding regeer en uitgebou tot 'n sterk en welvarende prinsdom. Toe hy die vakante Poolse kroon in 1575 vir homself ingepalm het, het hy sy broer Kristóf as goewerneur oor Transsilvanië aangestel en na Krakau verhuis waar hy homself toegespits op sy ideaal, naamlik die vestiging van 'n Oos-Europese ryk. Hierdie ideaal het as gevolg van verskeie redes, maar veral sy vroegtydige dood in 1586, nooit gerealiseer nie ook nie sy hoop dat hy Hongarye met Poolse hulp weer sou kon verenig nie. Sy neef, Zsigmond Báthory, het hom as prins opgevolg. Keiser Rudolf het intussen in 1576 by Maximilian II die beheer van die Habsburgse ryk oorgeneem.

Hernude aanvalle deur die Turke het daartoe gelei dat die Habsburgers hulleself in 1591 weer in 'n oorlog met die Turke begewe het. Transsilvanië en twee Roemeense prinsdomme het die Habsburgers in hierdie oorlog, wat vir meer as 'n dekade geduur het, bygestaan. Hierdie suksesvolle samewerking, maar ook die ongewilde onwilligheid van Zsigmond Báthory om teen die Turke te veg, het daartoe gelei dat hy Transsilvanië aan koning Rudolf van Habsburg oorhandig het. István Bocskai, voormalige raadgewer van Báthory, was egter nie bereid om Habsburgse heerskappy oor Transsilvanië te aanvaar nie. Met die hulp van die Turke en duisende huursoldate het hy die Habsburgers toe die stryd aangesê en uit talle stede verdryf. Onderhandelings wat op hierdie stryd gevolg het, het in 1606 uitgeloop op die Vredesverdrag van Wene waarkragtens die onafhanklikheid van die prinsdom van Transsilvanië weer deur die Habsburgers erken is. Bocskai is daarna deur die adelstand tot prins van Transsilvanië gekies met die medewete en instemming van die sultan (kyk Pamlényi 1973:147). 
Die Hervorming het in aldrie dele van Hongarye grondgevat - eerstens in Transsilvanië waar Johannes Honterus (1498 - 1549) die eerste Lutherse hervormer was (kyk Bakhuizen van den Brink \& Dankbaar 1967:128, 129) en waar koning János Zsigmond na die Protestantisme oorgeloop het; daarna in die gebied onder Turkse beheer, waar die Protestantisme verdra is omdat dit teen Rome gerig was, en laastens ook in die westerse koninkryk waar Ferdinand I en later ook sy seun, Maximilian I, die Hervorming op grond van politieke redes tot 'n sekere mate wel sy gang laat gaan het (kyk Szabó 1927:11).

\subsection{Hongaarse Kerkhervormers}

Die meeste bronne wat oor die Kerkhervorming handel, vermeld die name van vyf prominente Hongaarse kerkhervormers wat spesiale vermelding verdien: Mátyás Biró van Déva (1500-1545), Mihály Sztárai (?-1575), István Kis van Szeged (1505-1572), Gál Huszár (?-1575) en Péter Juhász Méliusz (1515-1572).

\subsubsection{Mátyás Biró}

Mátyás Biró, wat ook bekend staan as die Hongaarse Luther en in Krakau en later ook in Wittenberg onder Luther en Melanchthon studeer het, het in 1531 Protestants geword. By sy terugkeer in Hongarye het hy 'n dokument met die titel Rudimenta salutis gepubliseer na aanleiding waarvan hy in die kasteel van Buda opgesluit is. In 1533 het hy met die hulp van vriende ontsnap, maar is kort daarna weer gevange geneem. Tydens sy gevangenskap het hy baie geskryf maar slegte sig het sy skryfwerk met verloop van tyd bemoeilik. Toe hy twee jaar later vrygelaat is, is hy Duitsland toe vir mediese advies. Nadat hy in 1538 na Hongarye teruggekeer het, het hy met groot ywer gepreek en onder andere 'n kerkskool te Ujsziget gestig (kyk Bakhuizen van den Brink \& Dankbaar 1967: 130). In 1541 moes hy egter weer na Duitsland uitwyk en ná sy terugkeer, twee jaar later, het hy tot met sy dood in 1545 'n vurige prediker gebly (kyk Révész 1956:12).

\subsubsection{Mihály Sztárai}

Mihály Sztárai, wat in Padua in Italië gepromoveer het, was as kapelaan betrokke by die slag te Mohács. Hy was die bekendste Hervormer in die suid-weste van Hongarye, waar hy 120 gemeentes gestig en vir elkeen 'n kerkgebou laat oprig het. Dit het hom in groot onguns gebring by die Rooms-Katolieke priesters en hulle het hom heftig teengestaan. 'n Legende wat in latere jare vertel is, 
verduidelik die omvang daarvan: “... he never stepped out of his front-door after dark without first pushing a pumpkin on a stick in front of him. Again and again the pumpkin was struck to the ground, split in two, instead of Sztárai's head" (Révész 1956:14). Sztárai is veral bekend vir sy verwerking van die psalms, die gesange wat hy geskryf en self getoonset het, die godsdienstige verhoogstukke wat hy saamgestel het en die talryke skole wat hy gestig het.

\subsubsection{István Kis}

István Kis was waarskynlik die mees geleerde Hongaarse Hervormer. Hy het in Wene, Krakau en Wittenberg studeer en oral met die hoogste lof geslaag. Kort ná sy terugkeer na Hongarye in 1544, het hy 'n slagoffer van vervolging geword met die gevolg dat hy voortdurend op die vlug was. Die Rooms-Katolieke leier van Ráckeve, waar Kis onder andere gedien het, het hom byna laat doodslaan en op sy hele biblioteek van bykans 200 boeke beslag gelê. Byna aan die einde van sy aktiewe beroepslewe is hy na aanleiding van 'n preek wat hy aan die begin van 1561 gehou het en waarin hy beswaar gemaak het teen die gebruik van baie lidmate om hulle kinders heidense name te gee, deur die Turke in die tronk gegooi. Révész vertel dit soos volg:

An influential woman with the pagan name of Ursula (like she-bear) thought that Szegedi was aiming specifically at her, and in revenge she renounced him to the Turks as a spy. The Turks dragged him from one prison cell to another. His friends found that what the Turks were really wanting was to work up a feeling of pity for their prisoner so that they could exact a good ransom for his release.

(Révész 1956:16)

Die Turke het Kis, geboei met kettings aan sy hande en voete, in etlike dorpe uitgestal en die losprys telkens verhoog. Interessant genoeg het hulle hom toegelaat om tydens hierdie uitstallings te preek. Uiteindelik het die lidmate van sy gemeente hom losgekoop sodat hy met sy werk kon voortgaan. Sy mees bekende werke is eers ná sy dood gepubliseer: sy Assertio vera de Trinitate kort na sy dood deur Béza (1519-1605) in Geneve, sy Speculum romanorum pontificum in 1584 in Basel, sy Tabulae analyticae in Schaffhausen in 1592 en sy Theologiae sincerae loci communes de Deo et homines in 1608 in Basel (kyk 
Révész 1956:17). Hierdie werke, almal in Latyn, was selfs in die buiteland goed bekend (kyk Szabó 1927:11). Oor sy teologie sê Révész:

He is much less of a mystic than are Calvin or Béza. His writings are the essence of Reformed theology, and just for that reason they show no one-sided leaning to any particular school of thought. Yet we might say that his theology is that of the Swiss Reformation, though his particular shade is more nearly that of Bullinger than of Calvin.

(Révész 1956:17)

\subsubsection{Péter Juhász Méliusz}

Péter Juhász Méliusz, ook 'n student van Wittenberg, was een van die eerste Hongaarse Hervormers wat die Calvinisme in Hongarye sterk gepropageer het. Hier moet in gedagte gehou word dat Johannes Calvyn (1509-1564) eers in 1536 met die verskyning van die eerste druk van sy Institusie op die openbare toneel verskyn het (kyk Van Schelven 1965:130). Die Hervormingsbeweging was op daardie stadium reeds stewig in Hongarye gevestig. Calvyn se leerstellings het dus eers heelwat later in Hongarye bekend geword. Méliusz het die Calvinisme veral onder die adelstand bevorder en met hulle steun het die Calvinisme groot veld gewen, veral in Debrecen in die ooste van die land. Hierdie stad het later bekend geword as die Calvinistiese Rome en Meliusz as die Hongaarse Calvyn (kyk Szabó 1927:18).

Church life in Debrecen clearly followed the model set at Zurich. The most important feature of the divine service was the preaching of God's word in the language of the people. Bishop Méliusz Juhász also imitated the lively interest of the Helvetian Reformation in public order, social life, education, law and order, and even in the physical and spiritual welfare of the inhabitants.

(HKH 1997:9)

Méliusz was ook 'n baie groot bestryder van die Unitarisme en saam met István Kis verantwoordelik vir die opstel van die Confessio ecclesia Debrecentis ter verdediging teen die beskuldigings van die Jesuïete, wat die Kontrareformasie in Hongarye gelei het (kyk Bakhuizen van den Brink \& Dankbaar 1967:130). Méliusz was 'n ywerige skrywer en het gedurende sy leeftyd 'n aantal geloofsbelydenisse, 'n sangbundel en talle preke gepubliseer. 


\subsubsection{Gal Huszár}

Gal Huszár was die mees prominente Hervormer in die noord-weste van Hongarye, wat toe onder die heerskappy van Ferdinand I gestaan het. Hy het ook teenstand ondervind en is in $\mathbf{1 5 5 4}$ onder andere belet om te preek en by meer as een geleentheid in die tronk gestop. Oral waar hy gekom het, het hy sy drukpers opgestel en groot hoeveelhede sangbundels gedruk. Sy teologiese posisie is moeilik om te bepaal aangesien dit wil voorkom asof die feite hulleself weerspreek. Hy het enersyds nooit beswaar gemaak teen die Lutherse vorm van erediens of Luther se leerstellings oor die nagmaal nie, maar andersyds tog met groot aanvaarding in gebiede gewerk waar die Switserse oortuigings baie gewild was. "We actually find him writing in 1557 to Bullinger, Zwingly's successor, asking him to suggest how the Hungarian form of service might be best unified; and then we find him publishing on his printing press Bullinger's reply, in which the latter outlines a purely Helvetic form of worship" (Révész 1956:18). Gal Huszár se volledige brief verskyn in die bekende Nederlandse kerkhistorikus, F Lampe, se Historia ecclesia reformatae in Hungaria et Transylvania (kyk Lampe 1728:112-116). Hierdie publikasie is, waarskynlik om meer gesag daaraan te verleen, in die naam van Lampe uitgegee terwyl dit in werklikheid 'n werk van een van sy Hongaarse studente, Pál Ember van Debrecen, was. Die feit dat Lampe dit onder sy eie naam uitgegee het, bevestig die uitstaande gehalte van hierdie werk. Lampe was ook behulpsaam met die verskyning van verskeie uitgawes van die eerste volledige Bybel in Hongaars. Huszár se versoek om 'n liturgie vir die Hongaarse erediens is egter deur Bullinger se skoonseun, Ludwig Lavater, uitgevoer en dit het in 1559 in Zürich verskyn onder die titel: De Ritibus et Institutis ecclesiae Tigurinae opusculum (sien Zsindely 1967:74).

\subsection{Die invloed van Heinrich Bullinger}

Die grootste invloed op die Kerkhervorming in Hongarye is ongetwyfeld deur Bullinger (1504-1575) uitgeoefen, nie net vanweë die feit dat sy persoonlike belydenis, die Confessio Helvetica Posterior later deur die Hervormde Kerk van Hongarye as belydenisskrif aanvaar is nie, maar as gevolg van ' $n$ jarelange verbintenis met die Hongaarse volk en kerk. Sy belangstelling in Hongarye het waarskynlik ontstaan na aanleiding van die gebeure te Mohács. Die hele Europa was die Hongare daarna uiters simpatiek gesind en terselfdertyd vervul met vrees en bewing vir die Turke. Bullinger het toonaangewende mense van baie lande gereeld met sy omvangryke korrespondensie op hoogte gehou van die 
toestande in Hongarye. Sy literêre nalatenskap bevat meer as 12,000 briewe meer as wat Luther, Zwingli en Calvyn gesamentlik geskryf het (kyk Zsindely 1967:57).

Die korrespondensie tussen Bullinger en János Fejérthóy, Sekretaris van die Hongaarse Kanselierskantoor in Wene, verdien spesiale vermelding. Op 26 Maart 1551 skryf Fejérthóy 'n brief aan Bullinger (kyk Zsindely 1967:69) waarin hy eerstens sy dank betuig omdat Bullinger die Hongaarse volk met sy geleerde geskrifte teruggelei het na die ware Christendom, sodat die evangelie in Hongarye, Thracië en selfs tot in Konstantinopel vrylik verkondig kan word, behalwe in dié dele van Hongarye waar die Roomse biskoppe die predikante vervolg. Fejérthóy vra vir vertroosting en versterking vir hierdie predikante en vir bemoediging vir die gemeentes. Vervolgens vra hy antwoorde op die volgende drie vrae:

\begin{abstract}
Watter standpunt moet die predikante inneem ten opsigte van die tweede huwelik wanneer die Turke 'n huweliksmaat ontvoer, die oorblywende huweliksmaat mettertyd weer trou, maar die eerste man of vrou tog uit gevangenskap terugkeer? Hoe moet die lidmate wat daartoe genoodsaak word om saam met papiste te woon, saam met hulle leef en hulle tog van die papiste se godsdienstige praktyke distansieer? Hoe moet lidmate antwoord op die argumente van die Roomse priesters wat hulle wil oorhaal of dwing tot die aanbidding van die brood van die mis?
\end{abstract}

\title{
(Zsindely, E 1967:69, soos vertaal deur K Papp)
}

Bullinger se spoedige antwoord op hierdie vrae bewys hoe ernstig hy die versoek opgeneem het. In Junie van dieselfde jaar antwoord hy met 'n baie uitvoerige dokument wat in meer as vyftig kort hoofstukke byna al die basiese vrae van die Christelike geloof en lewe kernagtig behandel. Vir agt jaar lank het hierdie dokument slegs in sy handgeskrewe vorm bestaan, maar in 1559 is dit gelyktydig deur twee Hervormde drukkers in twee verskillende stede uitgegee. In 1967, toe die Hervormde Kerk van Hongarye die 400-jarige jubileum van die aanvaarding van die Confessio Helvetica Posterior gevier het, is hierdie briewe in ' $n$ tekskritiese uitgawe van die oorspronklike Latynse teks saam met 'n Hongaarse vertaling daarvan uitgegee onder die titel: Heynrichi Bullingeri epistola ad Ecclesias Hungaricas earumque pastores scripta, MDLI. 


\section{DIE GEBOORTE VAN DIE HERVORMDE KERK VAN HONGARYE}

Met verloop van tyd het die Protestante in Hongarye hulle al hoe meer aan die kant van die Switserse Hervormers begin skaar. Die Sinode van Gönc aanvaar reeds in 1566 'n belydenis van Béza asook Bullinger se Confessio Helvetica Posterior (kyk Papp 1999:9) wat 'n jaar vantevore geskryf is. Op 22 Augustus 1567 aanvaar die Sinode van Debrecen ook die Confessio Helvetica Posterior tesame met die Heidelbergse Kategismus as belydenisskrifte van dié Kerk (kyk Tóth 1995:48). Hierdie datum word vandag beskou as die geboortedag van die Hervormde Kerk van Hongarye. Kontak met die Lutherse rigting het gevolglik geleidelik begin afneem, alhoewel sekere invloede permanent was: "The peculiarity of the situation in Hungary lay in this that the break with Lutheranism occurred only in the field of theology and not in that of church government. Thus the office of superintendent which is characteristic of the Hungarian Reformed Church was taken over as it stood from the Lutheran Church model" (Révész 1956:33).

Naas die liedereskat wat die Hongaarse Hervormers nagelaat het, was hulle vertaling van die Bybel in die spreektaal van die volk seker die grootste vrug van hulle arbeid. In 1541 verskyn die eerste volledige Hongaarse Nuwe Testament en elf jaar later ' $n$ nuwe vertaling daarvan asook ' $n$ gedeelte van die Ou Testament. Die eerste volledige Hongaarse Bybel verskyn in 1590. Dit is deur 'n aantal teoloë onder leiding van Gáspár Károlyi (1530-1591), predikant van Gönc, vertaal en in Vizsolyi gedruk met die hulp van 'n aantal ryk en magtige grondmagnate (kyk Papp 1999:9; Bitskey 1999:249).

\section{SLOTOPMERKINGS}

Die Kerkhervorming het in Hongarye soveel sukses gehad dat tussen $80 \%$ en $90 \%$ van die bevolking (bykans vier miljoen mense) aan die einde van die sestiende eeu Protestants was en dit het voorgekom asof die dae van die pous vir altyd getel was (kyk HKH 1997:7). As daar in gedagte gehou word dat hierdie sukses in een van die moeilikste tye in die geskiedenis van Hongarye behaal is, is dit des te meer merkwaardig.

Die sukses van die Kerkhervorming was egter van korte duur. Die geweldige teenstand en wrede vervolgings en strawwe tydens die Kontra- 
reformasie, het in die sewentiende eeu groot terugslae gebring, veral gedurende die jare 1671 tot 1681, wat later bekend sou word as die dekade van rou. Dit het tot gevolg gehad dat slegs ongeveer die helfte van die bevolking aan die begin van die agtiende eeu Protestants was.

Die teenstand teen die Protestantse kerke het in die agtiende eeu voortgeduur en tot gevolg gehad dat verdere verliese gely is. "Infolge all dieser Verfügungen hat sich bis Ende des XVIII. Jahrhunderts die Zahl der Katholiken derart vermehrt, dass sie den Protestanten fast dreifach überlegen war. (Gegen 1,983.366 Protestanten gab es 5,105.385 Katholiken" (Szabó 1927:36).

Die opkoms van die nasionalisme in die negentiende eeu het gepaard gegaan met groter toegewings aan die Protestantse kerke. Die uitbreek van die Vryheidsoorlog teen die Habsburgers in 1848 het egter voorkom dat die Protestante hulle nuutverworwe vryhede ten volle kon benut. Hulle vereenselwiging met die vryheidstrewe van die volk het egter daartoe bygedra dat die Hervormde Kerk van Hongarye, as die grootste Protestantse denominasie in Hongarye, met verloop van tyd kerk vir die volk én kerk van die volk begin word het. Die Hongare se neerlaag in die Vryheidsoorlog het egter verreikende gevolge vir die Protestantse kerke ingehou. Omdat die Hervormde Kerk van Hongarye as aanstigters van die vryheidstryd beskou is, is dié kerk met allerhande beperkings gestraf met die gevolg dat die lidmaattal in die volgende dekades aansienlik gedaal het en daar ' $n$ enorme insinking in die lewe van die kerk gekom het. Drastiese interne hervormings en 'n aksentverskuiwing in die bedieningstrategie het egter daartoe bygedra dat die kerk groot vooruitgang getoon het gedurende die laaste dekades van negentiende eeu en die eerste dekade van die twintigste eeu, ten spyte van die emigrasie van meer as 1,500,000 Hongare na Amerika: "According to the statistical data of 1910, the number of Reformed Hungarians was 2,620.000 (an increase of more than half a million since 1870) ... cared for by 2062 ministers, 454 professors and teachers, as well as 2965 primary schoolmasters" (HHK 1997:23-24).

Die veelbewoë geskiedenis van die Hongaarse volk gedurende die twintigste eeu is alombekend. Die tragiese gevolge van die Eerste Wêreldoorlog, Kommunistiese Rewolusie, Teenrewolusie, Vredesverdrag van Trianon, Tweede Wêreldoorlog en die kommunistiese oorname van Hongarye asook die Hongaarse Rewolusie van 1956 en die onderdrukking daarvan, het die lewe van die Hongaarse volk in alle fasette radikaal verander. Hongarye moes twee- 
derdes van sy grondgebied kragtens die Vredesverdrag van Trianon in 1920 aan Tsjeggië, Roemenië en Serwië afstaan en die Hervormde Kerk van Hongarye het meer as die helfte van sy lidmate verloor. Die emigrasiegolwe na die Tweede Wêreldoorlog en Hongaarse Rewolusie van 1956 het ook 'n enorme verlies aan lidmate tot gevolg gehad en die kerke in Hongarye het vir bykans veertig jaar 'n stryd om oorlewing gevoer.

Met die ineenstorting van die kommunisme in 1989, het die situasie egter weer geleidelik na normaal teruggekeer. Vanaf 1990 waarborg die Republiek van Hongarye weer godsdiensvryheid en onverstoorde godsdiensbeoefening in sy Grondwet. Die Hervormde Kerk van Hongarye kon sedertdien sonder enige inmenging van buite weer kerk wees.

Volgens die statistiek van 1995 was ongeveer $21 \%$ of 2200000 van die land se bevolking lidmate van die Hervormde Kerk van Hongarye. Die kerk het uit 1200 gemeentes bestaan met meer as 1400 kerkgeboue. Hierbenewens het die kerk in 1995 onder andere oor dertien tehuise vir bejaardes, gestremde kinders, afgetrede werknemers, 'n aftree-oord vir predikante, 'n kinderhospitaal, drie vlugtelingsentrums, 'n uitgewery en drukkery, verskeie konferensiesentrums, kampterreine en vakansiehuise, ses kleuterskole, agt en twintig laerskole, agtien hoërskole, veertien kolleges, twee teologiese akademies (Debrecen en Sárospatak) en 'n universiteit (Karolyi Gáspár Hervormde Universiteit in Budapest) beskik (kyk Tóth 1995:40-51).

\section{Literatuurverwysings}

Bakhuizen van den Brink, J N \& Dankbaar, W F 1968. Handboek der Kerkgeschiedenis Vierde Deel. 3de uitg. Den Haag: Bert Bakker.

Bitskey, I 1999. Spiritual life in the early modern age, in Kósa, L (ed), A cultural history of Hungary, from the beginnings to the eighteenth century, 229-285. Budapest: Corvina.

Bucsay, M 1977. Der Protestantismus in Ungarn 1521-1978: Ungarns Reformationskirchen in Geschichte und Gegenwart, Teil I: Im Zeitalter der Reformation, Gegenreformation und katoholischen Reform. Wien: Hermann Böhlaus.

Bucsay, M 1985. A Protestantizmus története Magyarországon 1521-1945 (Die geskiedenis van die Protestantisme in Hongarye 1521-945). Budapest: Gondolat. Hervormde Kerk van Hongarye 1997. Egyházunk: a Magyarországi Református Egyház/Our church: the Reformed Church in Hungary. Budapest: Kálvin János Kiadója.

Ignotus, P 1972. Hungary. London: Ernest Benn. 
Lampe, F 1728. Historia ecclesiae reformatae in Hungaria et Transylvania. Utrecht: Jacob van Pools.

Pamlényi, E (ed) 1973. A history of Hungary. 4th ed. Budapest: Corvina.

Papp, K 1999. Die eerste volledige Hongaarse Bybel: Ouer as die Statevertaling! Konteks 10(10), 8-9 en 15.

Papp, K D 2002. Die historiese agtergronde van die Hongaars-Afrikaanse predikantefamilie Papp. MA-verhandeling, Universiteit van Pretoria.

Révész, I 1956. History of the Hungarian Reformed Church. Washington: The Hungarian Reformed Federation of America.

Szabó, J S 1927. Der Protestantismus in Ungarn. Berlyn: Der Evangelische Bund.

Tóth, K (ed) 1995. Tájékoztató a magyarországi egyházakról (Information about the Churches in Hungary). Budapest: A Magyarországi Egyházak Ökumenikus Tanácsa (The Ecumenical Council of Churches in Hungary).

Zoványi, J 1921. A Reformáczió Magyarországon 1565-ig (Die Kerkhervorming in Hongarye tot 1565). Budapest: Jókai Nyomda.

Zsilinszky, M 1881. A Magyar országgyülések vallásügyi tárgyalásai .... (Die handelinge van die Hongaarse Nasionale Vergadering insake godsdienstige aangeleenthede ....), in Zoványi J, A Reformáczió Magyarországon 1565-ig (Die Kerkhervorming in Hongarye tot 1565), 30-54. Budapest: Jókai Nyomda.

Zsindely, E 1967. Bullinger Hendrik Magyar kapcsolatai (Hendrik Bullinger se bande met Hongarye), in Bartha, T (ed), A Il.Helvét Hitvallás Magyar-országon és Méliusz Eletmüve (Die tweede Helvetiese Konfessie in Hongarye en die lewenswerk van Mélius), 55-86. Budapest: Hervormde Kerk van Hongarye. 